\title{
PENGARUH PEMBELAJARAN DENGAN MODEL PROBLEM SOLVING FISIKA (PSF) TERHADAP PRESTASI BELAJAR DAN KEMAMPUAN BERPIKIR KRITIS
}

\author{
Mega Angellena*, Eko Swistoro, Desy Hanisa Putri
}

\author{
Program Studi Pendidikan Fisika, Fakultas Keguruan dan Ilmu Pendidikan, Universitas Bengkulu, \\ Jl. W.R Supratman Kandang Limun, Bengkulu \\ e-mail*: megaangellena@gmail.com
}

\begin{abstract}
ABSTRAK
Penelitian ini bertujuan untuk menguji pengaruh pembelajaran dengan model Problem Solving Fisika (PSF) terhadap prestasi belajar dan kemampuan berpikir kritis pada siswa kelas X MIA di SMAN 4 Kaur. Penelitian ini menggunakan desain nonequivalent control group design untuk meneliti pengaruh model PSF terhadap prestasi belajar dan one group pretest posttest design untuk meneliti pengaruh model PSF terhadap kemampuan berpikir kritis. Sampel penelitian diambil menggunakan teknik purposive sampling sehingga diperoleh kelas X MIA 1 berjumlah 31 orang sebagai kelas eksperimen dan kelas X MIA 2 berjumlah 31 orang sebagai kelas kontrol. Data penelitian dikumpulkan dengan menggunakan tes prestasi belajar dan tes kemampuan berpikir kritis. Berdasarkan analisis data menggunakan uji-T dua sampel independen menunjukkan bahwa 1) tidak terdapat pengaruh yang signifikan pembelajaran dengan model PSF terhadap prestasi belajar dengan nilai $t_{\text {hitung }}<t_{\text {tabel }}$ yaitu $(1,23<2,00)$, dengan effect size sebesar 0,32 yang berada dalam kategori rendah. 2) terdapat pengaruh yang signifikan pembelajaran dengan model PSF terhadap kemampuan berpikir kritis diketahui dengan adanya selisih antara skor rata-rata posttest dengan skor rata-rata pretest sebesar 36,78, dengan effect size sebesar 3,21, yang berada dalam kategori kuat. Kesimpulan penelitian ini menunjukkan bahwa tidak terdapat pengaruh yang signifikan pembelajaran menggunakan model Problem Solving Fisika terhadap prestasi belajar siswa kelas X SMAN 4 Kaur dan terdapat pengaruh yang signifikan terhadap kemampuan berpikir kritis siswa kelas X SMAN 4 Kaur.
\end{abstract}

Kata Kunci: Model Problem Solving Fisika, prestasi belajar, Kemampuan Berpikir Kritis

\begin{abstract}
This study aimed to examine the effect of learning used the Problem Solving Fisika (PSF) learning Model on the learning achievement and critical thinking Skills of students of SMAN 4 Kaur. This research used nonequivalent control group design to examine the effect of the PSF learning model on learning achievement and one group pretest posttest design to examine the effect of the PSF learning model on Critical Thinking Skills. Samples in this research were taken by using purposive sampling. Data analysis which used the T-test two independent samples showed that 1) there was no significant effect of learning with the PSF learning model on the learning achievement with a value that was $\mathrm{t}_{\text {count }}<\mathrm{t}_{\text {table }}$ $(1.23<2.00)$, with effect size of 0,31 which were in the low category. 2$)$ there was a significant effect of learning with the PSF model on critical thinking skills known by the difference between the average Posttest score and average Pretest score (O2-O1) of 36,78, with effect size of 3,21, meant that the Problem Solving Fisika learning model had an effect of $98 \%$ and was in the High category. The conclusion of this study shows that there is no significant effect of learning using the Problem Solving Fisika learning model on the learning achievement and a significant effect of learning using the Problem Solving Fisika learning model on thecritical thinking skills.
\end{abstract}

Keywords: Model Problem Solving fisika, learning achievements, critical thinking ability

\section{PENDAHULUAN}

Pendidikan pada dasarnya adalah upaya meningkatkan kemampuan sumber daya manusia supaya dapat menjadi manusia yang memiliki karakter dan dapat hidup mandiri (1). Dengan kata 
lain Pendidikan merupakan upaya manusia untuk memperluas pengetahuan dalam rangka membentuk nilai, sikap, dan perilaku. Pendidikan juga merupakan salah satu sarana untuk mengembangkan potensi diri dan keterampilan melalui proses pembelajaran sebagai bekal bagi dirinya menjalani hidup bermasyarakat, berbangsa, dan bernegara. Pendidikan bukanlah sesuatu yang tetap melainkan sesuatu yang selalu berubah, sehingga menuntut adanya suatu perbaikan yang terus menerus (2). Pemerintah selalu berusaha untuk memperbaiki kualifikasi guru, pemerataan pendidikan, sarana dan prasarana. Pendidikan selalu mengalami pembaharuan dalam rangka mencari struktur kurikulum, sistem pendidikan, model pembelajaran, dan metode pembelajaran yang efektif dan efisien. Pendidikan di Indonesia telah mengalami beberapa kali pergantian kurikulum, kurikulum yang pernah diterapkan di Indonesia antara lain adalah kurikulum berbasis kompetensi, kurikulum tingkat satuan pendidikan dan kurikulum 2013 yang saat ini masih diterapkan.

Kurikulum 2013 diciptakan karena kerisauan melihat sistem pendidikan yang diterapkan selama ini hanya terbatas pada pengajaran untuk memenuhi target pengetahuan siswa saja. Selain pengetahuan, juga dibutuhkan kemampuan dan kepribadian yang teramat penting untuk mendapatkan lulusan yang berkompeten dan beretika untuk selanjutnya siap bersaing secara global. Kurikulum 2013 menggunakan pendekatan saintifik yang sesuai diterapkan pada pembelajaran, terutama pembelajaran Fisika (3). Fisika adalah ilmu yang mempelajari mengenai materi atau zat yang meliputi sifat fisis, komposisi, perubahan dan energi yang dihasilkan. Oleh sebab itu, perkembangan ilmu pengetahuan dan teknologi yang sangat pesat saat ini tidak bisa terlepas dari ilmu fisika sebagai salah satu ilmu dasar (4). Fisika adalah salah satu pelajaran yang tidak disukai oleh sebagian besar siswa SMP/SMA. Ketidaksukaan terhadap fisika ini dikarenakan siswa mengalami kesulitan belajar fisika. Selain itu observasi yang dilakukan dan pengamatan secara langsung di SMA Negeri 4 Kaur serta melalui wawancara yang dilakukan dengan guru fisika, SMA Negeri 4 Kaur adalah salah satu sekolah yang sudah menerapkan kurikulum 2013. Perangkat pembelajaran yang digunakan, secara umum sudah mengacu pada kurikulum 2013. Pada pembelajaran fisika saat ini guru menerapkan model pembelajaran salah satunya pembelajaran langsung. Akan tetapi tidak sedikit siswa yang mengalami kesulitan dalam memahami materi yang diberikan. Hal ini dapat dilihat dari rendahnya prestasi belajar siswa yang dibuktikan dengan hasil belajar fisika siswa yang masih belum optimal, terlihat dari ulangan harian yaitu hanya $20 \%$ saja siswa yang tuntas atau nilai diatas KKM, sedangkan $80 \%$ siswa belum mencapai nilai KKM.

Salah satu model pembelajaran yang dapat mengatasi kesulitan dalam pembelajaran fisika adalah model problem solving fisika. Problem Solving Fisika mampu meningkatkan pemahaman mahasiswa pada materi pembiasan sebesar 40,7\% dan meningkatkan kemampuan pemecahan masalah secara umum sebesar 83,3\% (5). Model pembelajaran Problem Solving Fisika mempengaruhi 76\% terhadap hasil belajar kognitif siswa kelas IX IPA SMA 1 Lebong (6). Selain itu menunjukan bahwa model Problem Solving Fisika memliki pengaruh terhadap kemampuan berpikir kritis(7). pembelajaran dengan menggunakan model pembelajaran Problem Solving Fisika dapat meningkatkan penguasaan konsep fisika dalam topik optika geometri (8). Selain itu, ada perbedaan hasil belajar fisika yang menggunakan model pembelajaran problem solving dan pembelajaran konvensional, dimana siswa yang menggunakan model problem solving memperoleh hasil belajar fisika yang lebih baik dibandingkan dengan pembelajaran konvensional (9).

Model pembelajaran PSF memiliki lima langkah pembelajaran, yaitu: 1) memahami masalah; 2) menjabarkan masalah ke dalam aspek fisika; 3) merencanakan pemecahan masalah; 4) menjalankan rencana; 5) evaluasi dan perluasan(10). Pembelajaran dengan menggunakan model Problem Solving Fisika melibatkan siswa aktif dalam memecahkan masalah dan menitikberatkan agar siswa mampu mengutarakan tujuan, menganalisa data, mengemukakan pendapat dan memberi keputusan ketika menghadapi suatu permasalahan di dalam proses pembelajaran fisika, selain itu juga membimbing siswa menjadi (pemecah masalah) problem solver yang berkompeten (8). Agar siswa menjadi problem solver yang berkompeten siswa harus memiliki kemampuan berpikir kritis karena setiap tahapan pemecahan masalah memerlukan kemampuan berpikir kritis dari siswa (11).

Dengan demikian, penelitian ini dirasa sangat penting dilakukan untuk mengetahui apakah

Pengaruh Pembelajaran dengan Model Problem Solving Fisika terhadap Prestasi Belajar dan Kemampuan Berpikir Kritis

Mega Angellena, Eko Swistoro, Desy Hanisa Putri 
Problem Solving Fisika memilik pengaruh terhadap prestasi belajar dan kemampuan berpikir kritis siswa. Oleh sebab itu judul penelitian ini yaitu "Pengaruh Pembelajaran dengan Model Problem Solving Fisika (PSF) terhadap Prestasi Belajar dan Kemampuan Berpikir Kritis di Kelas X SMA Negeri 4 Kaur" Berdasarkan uraian di atas di rumuskan masalah sebagai berikut: 1) Apakah terdapat pengaruh yang signifikan pembelajaran dengan model Problem Solving Fisika terhadap prestasi belajar siswa kelas X SMAN 4 Kaur?, 2) Apakah terdapat pengaruh yang signifikan pembelajaran dengan model Problem Solving Fisika terhadap kemampuan berpikir kritis siswa kelas X SMAN 4 Kaur?. Adapun tujuan dari penelitian ini adalah untuk mengetahui pengaruh model PSF terhadap prestasi belajar dan kemampuan berpikir kritis siswa kela X SMAN 4 Kaur.

\section{METODE PENELITIAN}

Jenis penelitian yang digunakan dalam penelitian ini adalah penelitian eksperimen. Penelitian ini dilakukan dengan menggunakan dua desain karena kemampuan berpikir kritis tidak diajarkan di kelas kontrol. Penelitian ini dilakukan pada bulan Maret 2020 di SMA Negeri 4 kaur. Sampel diambil dengan teknik purposive sampling adalah teknik melalui pertimbangan tertentu (12) misalnya melalui pertimbangan guru fisika yang mengajar di kelas X MIPA. Sebelum penentuan sampel dilakukan uji beda terhadap populasi yang hasilnya tidak ada perbedaan diantara kelas populasi. Kelas X MIPA 1 digunakan sebagai kelas eksperimen diajarkan menggunakan model PSF dan kelas X MIPA 2 digunakan sebagai kelas kontrol diajarkan menggunkan model pembelajaran yang biasa digunakan oleh guru yaitu Direct Instruction.

Data dikumpulkan melalui pretest dan posttest prestasi belajar dan kemampuan berpikir kritis. Sebelum instrument tes di uji coba terlebih dahulu dilakukan validasi ahli. Validasi dilakukan oleh 3 orang ahli mata pelajaran fisika yaitu satu orang guru fisika SMA dan dua orang dosen fisika dengan cara menyesuaikan instrumen tes dengan indikator yang telah dibuat. Setelah dinilai oleh 3 orang ahli mata pelajaran fisika selanjutnya dikonsultasikan kepada dosen pembimbing untuk diperbaiki, setelah diperbaiki kemudian di uji cobakan kepada responden yang mempelajari materi hukum Newton tentang gerak. Hasil uji coba digunakan untuk menentukan validitas soal, reliabilitas soal, tingkat kesukaran butir soal, dan daya pembeda butir soal.

Tes prestasi diberikan di kelas eksperimen dan kelas kontrol, sedangkan tes kemampuan berpikir kritis hanya diberikan di kelas eksperimen. Pengaruh model PSF terhadap prestasi belajar dianalisis menggunakan uji $\mathrm{t}$ terhadap rata-rata hasil posttest kedua kelas karena data posttest berdistribusi normal dan homogen, serta data pretest yang menunjukkan tidak ada perbedaan. Sedangkan pengaruh model PSF terhadap kemampuan berpikir kritis diukur dengan menghitung selisih posttest dan pretest. Setelah dilakukan analisis didapatkan bahwa model PSF tidak berpengaruh signifikan terhadap prestasi belajar dengan taraf signifikan 0,05 dan berpengaruh signifikan terhadap kemampuan berpikir kritis, maka dilakukan uji lanjut untuk mengukur seberapa besar pengaruh model PSF terhadap prestasi belajar dan kemampuan berpikir kritis dengan effect size.

2.1 Perhitungan normalitas

Adapun rumus yang digunakan untuk menguji normalitas suatu kelas adalah menggunakan rumus chi kuadrat (13) yaitu sebagai berikut:

$$
x^{2}=\sum \frac{\left(f_{0}-f_{h}\right)^{2}}{f_{h}}
$$

$x^{2}$ adalah chi kuadrat hitung, $f_{h}$ adalah frekuensi pengamatan sampel $f_{0}$ adalah frekuensi teoritik.

2. 2 Uji homogenitas

Uji homogenitas dapat dihitung dengan menggunakan uji Harley yaitu sebagai berikut:

$$
f_{\text {hitung }}=\frac{s_{1}^{2}}{s_{2}^{2}}
$$


$s_{1}^{2}$ adalah variansi terbesar sedangkan $s_{2}^{2}$ adalah variansi terkecil. Sampel dikatakan homogen apabila $f_{\text {hitung }}$ lebih kecil daripada $f_{\text {tabel }}$ pada taraf signifikan $(\alpha)=5 \%$ Secara matematis dapat ditulis $f_{\text {hitung }}<f_{\text {tabel }}$ pada derajat kebebasan dalah pembilang (varian terbesar) dan penyebut (varians terkecil).

2.3 Uji parametric

Untuk menguji prestasi belajar maka dilakukan uji perbedaan antara prestasi belajar kelas eksperimen dan prestasi belajar kelas kontrol. Yang mana data diambil dari dua sampel yang independent atau tidak saling mempengaruhi. Adapun rumus yang digunakan yaitu persamaan berikut (14):

$$
t=\frac{\overline{x_{1}}-\overline{x_{2}}}{\sqrt{\frac{\left(n_{1}-1\right) s_{1}^{2}+\left(n_{1}-1\right) s_{2}^{2}}{n_{1}+n_{2}-2}\left(\frac{1}{n_{1}}+\frac{1}{n_{2}}\right)}}
$$

$\mathrm{t}$ adalah nilai t hitung, $\bar{x}_{1}$ adalah nilai rata-rata kelompok 1, $\bar{x}_{2}$ adalah nilai rata-rata kelompok2, $n_{1}$ adalah jumlah sampel kelompok $1, n_{2}$ adalah jumlah sampel kelompok $2, s_{1}^{2}$ adalah varian kelompok 1, dan $s_{2}^{2}$ adalah varian kelompok 2

Kriteria pengambilan keputusan pada uji hipotesis dengan uji-t adalah jika $t_{\text {hitung }}$ lebih besar dari $t_{\text {tabel }}$, maka Ha diterima dan Ho ditolak dengan signifikan derajat kepercayaan $(\alpha)$ yang digunakan yaitu $5 \%$ atau $0,05 . t_{\text {tabel }}$ didapat dari tabel distribusi t dengan $\mathrm{dk}=n_{1}+n_{2}-2$.

\subsection{Uji besar pengaruh}

Untuk mengetahui besar pengaruh dilakukan uji effect size. Effect size adalah ukuran mengenai besarnya efek atau pengaruh suatu variabel terhadap variabel lainnya (15). Perhitungan effect size untuk mengukur besar pengaruh model pembelajaran Problem Solving Fisika terhadap prestasi belajar dilakukan dengan rumus Cohen's $d$,

$$
d=\frac{\overline{X_{E}}-\overline{X_{C}}}{\overline{S_{\text {Pooled }}}}
$$

Dimana,

$$
s_{\text {pooled }}=\sqrt{\frac{\left(n_{E}-1\right) s_{E}^{2}+\left(n_{C}-1\right) s_{C}^{2}}{n_{E}+n_{C}-2}}
$$

D adalah besar pengaruh, $\bar{X}_{E}$ adalah skor rata-rata posttest kelas eksperimen, $\bar{X}_{C}$ adalah skor rata-rata posstest kelas control, $s_{E}^{2}$ :varians kelas eksperimen, $s_{E}^{2}$ adalah varians kelas control.

Tabel 1. Interpresetasi besar effect size

\begin{tabular}{cc}
\hline Besar d & Interprestasi \\
\hline $\mathrm{d} \geq 0,8$ & Tinggi \\
$0,5 \leq \mathrm{d}<0,8$ & Sedang \\
$\mathrm{d}<0,5$ & Rendah \\
\hline
\end{tabular}

\section{HASIL DAN PEMBAHASAN}

\subsection{Pengaruh Model PSF terhadap Prestasi Belajar}

Berdasarkan data hasil penelitian pretest dan posttest prestasi belajar pada dua kali pertemuan pada kelas eksperimen didapat data sebagai berikut. Grafik data hasil pretest dan posttest prestasi belajar pada kelas eksperimen dapat dilihat dalam gambar 1. 


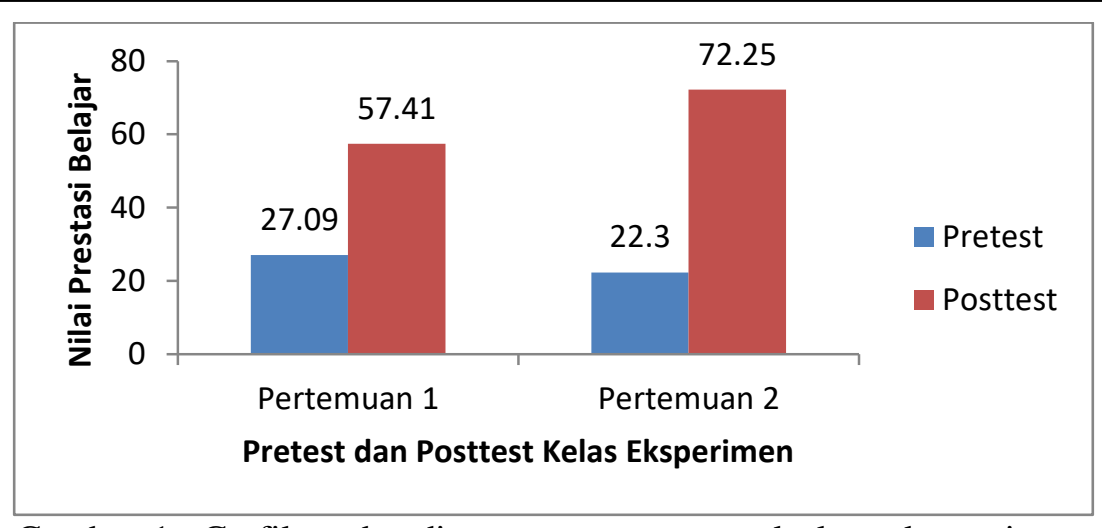

Gambar 1. Grafik perbandingan pretest posttest kelas eksperimen

Pada kelas kontrol juga didapat data hasil pretest dan posttest prestasi belajar pada dua kali pertemuan. Pada pertemuan pertama diperoleh skor rata-rata pretest sebesar 27,09 dan nilai ratarata posttest 56,45. Pertemuan kedua diperoleh skor rata-rata pretest sebesar 24,41 dan skor ratarata posttest sebesar 66,38. Dari kedua pertemuan rata-rata pretest sebesar 25,75 dan rata-rata posttest sebesar 61,45. Grafik data hasil pretest dan posttest prestasi belajar pada kelas kontrol dapat dilihat dalam gambar 2.

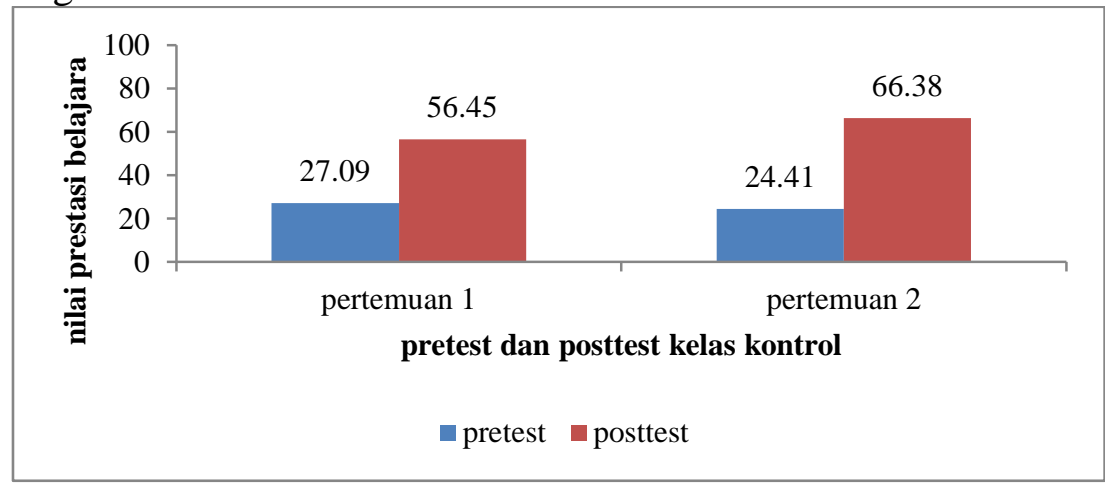

Gambar 1. Grafik Batang Rata-rata Pretest dan Posttest Kelas Kontrol

Pada kelas eksperimen, setelah diberikan perlakuan pembelajaran berupa model Problem Solving Fisika skor rata-rata posttest mencapai 65,11, sedangkan kelas kontrol yang diajarkan dengan model direct instruction rata-rata posttest mencapai 61,41. Grafik rata-rata posttest kelas eksperimen dan kelas kontrol dapat dilihat pada gambar 3.

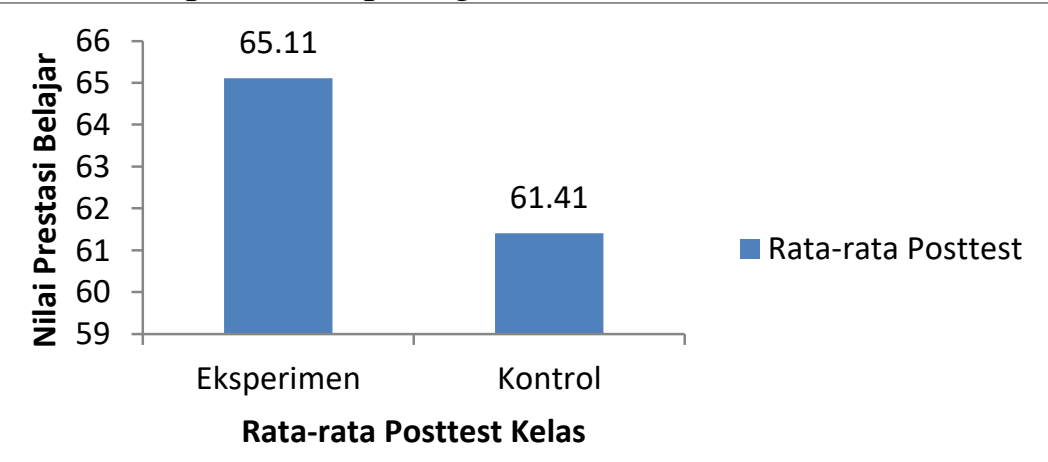

Gambar 2 Grafik Skor Rata-rata Posttest Kelas Eksperimen dan Kelas Kontrol

Berdasarkan grafik dalam gambar 3 terlihat bahwa skor rata-rata posttest kelas eksperimen lebih tinggi dibandingkan kelas kontrol. Akan tetapi berdasarkan uji perbedaan (uji t) terlihat bahwa $\mathrm{t}$ hitung lebih kecil dari $\mathrm{t}$ tabel pada taraf signifikansi $5 \%$ dengan $\mathrm{dk}=60$ yang berarti perbedaan tidak signifikan antara kelas eksperimen dan kelas kontrol dengan kata lain tidak terdapat pengaruh yang signifikan model Problem Solving Fisika terhadap prestasi belajar siswa kelas X SMA N 4 Kaur ( di tolak dan di terima). 
Selanjutnya untuk mengukur seberapa besar pengaruh (effect size) yang diberikan oleh pembelajaran dengan menggunakan model Problem Solving Fisika terhadap prestasi belajar, perlu dilakukan uji lanjut menggunakan rumus Cohen's. Hasil perhitungan yang diperoleh menunjukkan bahwa pengaruh yang diberikan oleh pembelajaran menggunakan model Problem Solving Fisika berada dalam kategori rendah, yaitu sebesar 0,32.

Siswa yang belajar menggunakan model Problem Solving Fisika mendapatkan hasil belajar yang lebih tinggi dibandingkan siswa yang belajar menggunakan model direct instruction. Berdasarkan grafik terlihat bahwa nilai posttest kelas eksperimen lebih besar kelas kontrol. Akan tetapi selisih nilai rata-rata posttest antara kelas ekperimen dengan kelas kontrol setelah di analisis dengan menggunakan uji $\mathrm{t}$ mendapatkan hasil bahwa perbedaan antara kelas eksperimen tidak signifikan terhadap kelas kontrol. Hasil dari penelitian tidak sejalan dengan penelitian terdahulu (8) Hal ini dipengaruhi oleh bebrapa faktor salah satunya data hasil belajar yang didapatkan hanya sampai pada pertemuan kedua saja sehingga perbedaan antara kelas eksperimen dan kontrol belum terlalu terlihat. Selain itu siswa SMA N 4 Kaur belum terbiasa untuk belajar menemukan pemecahan masalah dikarenakan selama ini pembelajaran fisika siswa SMA N 4 Kaur hanya berpusat kepada guru.

\subsection{Pengaruh Model PSF terhadap Kemampuan Berpikir Kritis}

Kemampuan berpikir kritis dalam penelitian ini dilakukan di kelas eksperimen. Data kemampuan berpikir kritis dalam penelitian ini didapat dari hasil pretest dan posttest siswa di kelas eksperimen yang diajarkan menggunakan model problem solving fisika. Siswa diberikan tes berupa kemampuan berpikir kritis dalam bentuk soal essay berjumlah 3 soal yang diberikan bersamaan dengan tes prestasi belajar.

Dalam penelitian ini, indikator kemampuan berpikir kritis (16) yang diukur yaitu: 1) memberikan Penjelasan Sederhana (menjawab pertanyaan) 2) membangun keterampilan dasar (mempertimbangkan apakah sumber dapat di percaya), 3) menyimpulkan (menginduksi dan mempertimbangkan hasil induksi). Alasan menggunakan indikator kemampuan berpikir kritis tersebut karena indikator berkaitan dengan langkah-langkah model pembelajaran Problem Solving Fisika.

Berdasarkan data hasil penelitian pretest dan posttest kemampuan berpikir kritis pada dua kali pertemuan pada kelas eksperimen didapatkan data yaitu pada pertemuan pertama rata-rata pretest adalah 33,33 dan rata-rata posttest adalah 69,56. Pada pertemuan kedua, rata-rata pretest adalah 39,42 dan rata-rata posttest adalah 76,70. Dari kedua pertemuan rata-rata pretest adalah 36,57 dan rata-rata posttest adalah 73,11.

Berdasarkan hasil yang diperoleh, adanya peningkatan kemampuan berpikir kritis siswa yang diajarkan dengan model problem solving fisika. Hal ini ditunjukkan dari perbedaan antara skor ratarata pretest dan skor rata-rata posttest yang diperoleh siswa cukup jauh. Berdasarkan hasil perhitungan, selisih antara rata-rata pretest dan posttest adalah sebesar 36,78. Karena terdapat selisih dari hasil perhitungan tersebut, maka dapat disimpulkan bahwa pembelajaran dengan model Problem Solving Fisika memberikan pengaruh terhadap kemampuan berpikir kritis siswa pada kelas eksperimen.

Selanjutnya untuk mengukur seberapa besar pengaruh (effect size) yang diberikan oleh pembelajaran dengan menggunakan model Problem Solving Fisika terhadap kemampuan berpikir kritis, perlu dilakukan uji lanjut menggunakan rumus Cohen's. Hasil perhitungan yang diperoleh sebesar 3,2 menunjukkan bahwa pengaruh yang diberikan oleh pembelajaran menggunakan model Problem Solving Fisika berada dalam kategori kuat. Artinya model Problem Solving Fisika memberikan pengaruh positif terhadap kemampuan berpikir kritis. Hasil yang didapat dalam penelitian ini sejalan dengan penelitian yang berjudul "Model Pembelajaran Problem Solving Untuk Meningkatkan Pemahaman Konsep dan Keterampilan Berpikir Kritis Siswa Sekolah Menengah Atas" yang menyatakan bahwa pembelajaran dengan menggunakan model problem solving dapat meningkatkan kemampuan memecahkan masalah dan kemampuan berpikir tingkat tinggi (kemampuan berpikir kritis dan kreatif (17). 
IV. SIMPULAN DAN SARAN (Times New Roman 12, huruf kapital, bold)

\subsection{Simpulan}

Berdasarkan hasil analisis data penelitian dan pembahasan, kesimpulan dalam penelitian ini adalah sebagai berikut: (1)Tidak terdapat pengaruh yang signifikan pembelajaran dengan model Problem Solving Fisika terhadap prestasi belajar pada materi hukum Newton di kelas X SMA N 4 Kaur. Hal ini terlihat dari hasil uji t-test polled varian yang menunjukkan bahwa hasil $t_{\text {hitung }}$ lebih kecil daripada $t_{\text {tabel }}(1,23<2,00)$, terbukti bahwa hipotesis $\left(H_{01}\right)$ yang diajukan dapat diterima. (2) Terdapat pengaruh yang signifikan penggunaan model pembelajaran Problem Solving Fisika terhadap kemampuan berpikir kritis siswa materi hukum Newton. Hal ini ditunjukkan dengan adanya selisih skor rata-rata posttest dengan skor rata-rata pretest $(\mathrm{O} 2-\mathrm{O} 1)$ sebesar 36,78 , terbukti bahwa hipotesis $\left(H_{a 2}\right)$ yang diajukan di terima. (3) Besar pengaruh (effect size) model Problem Solving Fisika terhadap prestasi belajar sebesar 0,32, Sehingga pengaruh model Problem Solving Fisika terhada prestasi belajar siswa kelas X SMAN 4 Kaur dikategorikan rendah. (4) Besar pengaruh model Problem Solving Fisika terhadap kemampuan berpikir kritis sebesar 3,21, sehingga pengaruh model Problem Solving Fisika terhadap kemampuan berpikir kritis dikategorikan kuat.

\subsection{Saran}

Berdasarkan penelitian yang telah dilakukan, disarankan beberapa hal yaitu: (1)Mengingat kelemahan model Problem Solving Fisika ini yaitu memerlukan banyak waktu, maka guru harus dapat mengatur alokasi waktu dengan sebaik baiknya pada saat pembelajaran berlangsung agar pembelajaran dengan model Problem Solving Fisika bisa dilakukan dengan efektif. (2)Bagi peneliti lanjutan, perlu dilakukan penelitian sejenis dengan menerapkan model Problem Solving Fisika untuk materi pembelajaran yang lain. Sehingga dapat diketahui sejauh mana pengaruh penggunaan model pembelajaran Problem Solving Fisika.

\section{DAFTAR PUSTAKA}

1. Sabar Budi Raharjo. Pendidikan Karakter Sebagai Upaya Menciptakan Akhlak Mulia. J Pendidik dan Kebud. 2010;16(3):229-38.

2. Sinambela. kurikulum 2013 , guru , siswa , afektif, psikomotorik, kognitif. 2013;17-29.

3. Sunarti, Rahmawati. Penelitian Dalam Kurikulum 2013. Yogyakarta: , C.V Andi Offset; 2014.

4. P SMPNST, Syahputri R. PENGARUH MODEL PEMBELAJARAN PROBLEM SOLVING TERHADAP HASIL BELAJAR FISIKA SISWA KELAS VIII. J Inpafi. 2014;2(4):1-9.

5. Warimun. Pengembangan Kemampuan Problem Solving Melalui Pembelajaran Topik Optika Fisis Bagi Mahasiswa Calon Guru Fisika. Pros Semirata BKS-PTN MIPA 2012. 2012;4:389_ 393.

6. Veronica T, Swistoro E, Hamdani D. Pengaruh Pembelajaran dengan Model Problem Solving Fisika terhadap Hasil Belajar dan Kemampuan Pemecahan Masalah Fisika Siswa Kelas XI IPA SMAN 1 Lebong. J kumparan Fis. 2018;1:31-9.

7. Handayani MW, Swistoro E, Risdianto E. Pengaruh Model Pembelajaran Problem Solving Fisika terhadap Kemampuan Penguasaan Konsep dan Kemampuan Pemecahan Masalah Siswa Kelas X MIPA SMAN 4 Kota Bengkulu. J kumparan Fis. 2018;1:36-44.

8. Warimun. Pengembangan Kemampuan Problem Solving melalui Pembelajaran Topik Optika Bagi Mahasiswa Calon Guru Fisika. In: disertasi. bandung: tidak di terbitkan; 2010.

9. Sijabat, Motlan, Derlina. Pengaruh Model Pembelajaran Model Problem Solving Dan Pemahaman Konsep Terhadap Hasil Belajar Fisika Siswa. J Pendidik Fis. 2010;(20):1-12. 
10. Yeni L, Eko S, Andik P. Pengaruh Pembelajaran dengan Model Problem Solving Fisika terhadap Hasil Belajar dan Kemampuan Pemecahan Masalah Fisika Siswa Kelas XI IPA SMAN 1 Lebong. J kumparan Fis. 2019;1:31-9.

11. Haryani D, Palangkaraya U. PEMBELAJARAN MATEMATIKA DENGAN PEMECAHAN MASALAH. Pros Semin Nas penelitian, Pendidik dan penerapan MIPA Univ negeri Yogyakarta. 2011;121-6.

12. Jihad, Haris. evaluasi pendidikan. Yogyakarta: Multi Presindo; 2012.

13. Sugiono. metode peneltian pendidikan. bandung: Alfabeta; 2010.

14. Sugiono. metode penelitian pendidikan. bandung: alfabeta; 2012.

15. Syahputri R. PENGARUH MODEL PEMBELAJARAN PROBLEM SOLVING TERHADAP HASIL BELAJAR FISIKA SISWA KELAS VIII SMP NEGERI 1 SIPISPIS T.P. 2012/2013. J Inpafi. 2014;1-9.

16. Arthur L, Costa AL. Revised Edition , Volume 1 Edited by. alexandria: Association for Supervision and Curriculum Development; 1991.

17. Warimun, Murwaningsih. Model Pembelajaran Problem Solving Untuk Meningkatkan Pemahaman Konsep dan Keterampilan Berpikir Kritis Siswa Sekolah Menengah Atas. J Pendidik Mat Dan Sains. 2013;11:26-8. 